\title{
An alloy made from art and activism, in North Macedonia.
}

\author{
BLACKWOOD, J.
}

2020

This is an Accepted Manuscript of a book chapter published by Routledge in Art and Activism in the Age of Systemic Crisis on 7.10.2020, available online:

http://www.routledge.com/9780367219840 


\section{An Alloy made from Art and Activism, in North Macedonia}

Jon Blackwood

Abstract

This paper traces the development of an "alloy" of artist and activist strategies in the context of North Macedonia, during the years of Nikola Gruevski's right- wing conservative government (2016-16) and its turbulent overthrow; the essay concludes by assessing the conditions for art in the "new normality" of Zoran Zaev's socialdemocrat led government from April 2017, onwards.

I outline the historical development of Macedonia since independence in the first section and discuss the characteristics of Gruevski's government. Critical to their cultural policy was the controversial Skopje 2014 scheme and "antiquisation"; the recasting of the appearance of Yugoslav-era Skopje in neoclassical and Baroque architectural styles and monuments. The response of critical artists to this scheme then is assessed through the example of Aleksandar Spasoski's The Ship that Never Sailed (2012), and the work of the KOOPERACIJA grouping.

Following a tracing of the fall of Gruevski and the Colour Revolution of $2015 / 16$, the essay assesses the conditions of the "new normality" in the country. Observing that an ever-strengthening alloy between art and activism had developed during these years of upheaval, analysis is provided of the operation and consequences of this co-operation, in relationship to the TEKSTIL cultural centre in Štip, and the online Arhiva ZAUM run by OPA Fondacija.

Bio:- Jon Blackwood is a reader in contemporary art at Gray's School of Art, Robert Gordon University, Aberdeen. He has written extensively on modern and contemporary art in the countries of the former Yugoslavia, and has curated exhibitions internationally. He divides his time between Aberdeen, Skopje and Sarajevo.

It is quite a rare experience to write an essay on contemporary art and activism in a state whose name changes officially, during the writing process. Yet, on 12 February 2019, the former "Former Yugoslav Republic of Macedonia" or "Republic of Macedonia", after nearly thirty years of diplomatic wrangling, officially changed its 
name to the "Republic of North Macedonia." This brought to an end not only a long period of uncertainty and existential isolation in international relations, but also closed, symbolically, a much more complicated and divided chapter in the region's history.

It is this latter series of debates, the constant over-writings and re-tellings of the story of Macedonia / North Macedonia, and the development of contemporary art and activism running alongside these, that will form the basis of this chapter. In what follows, I will briefly outline the cultural ecology and trajectory of North Macedonia and then, through specific case studies, discuss the role that art, activism, and artactivism, has played in these developments; a continually tempered and strengthening alloy of affinity, throughout this period. It should be noted that such art-activism has been rooted in opposition to a right wing populist government, and its symbolic architectural re-casting of the country under a controversial "antiquisation" policy; an architectural scheme called Skopje 2014.

\section{From FYROM to North Macedonia}

The Republic of Macedonia voted to secede from the Yugoslav federation on 8 September 1991. This was the beginning of a period in Macedonia's history that seemed to be in a permanent liminal state; the country suffered from a long international isolation from the 1990s, owing to Greek objections to the country's name and flag ${ }^{1}$; in 2001, an insurgency in the north-west saw a small but vicious war fought between ethnic Macedonians and Albanians, in the short lived so-called Macedonian insurgency ${ }^{2}$, in part an aftershock of the 1999 Kosovo conflict.

The Nikola Gruevski epoch in Macedonia began in 2006, with the election of a conservative nationalist government. Gruevski was leader of the Internal Macedonian Revolutionary Organisation- Democratic Party for Macedonian National Unity (VMRO-DPMNE) ${ }^{3}$. This is the biggest right wing party in the country, tracing its roots to Macedonian secessionist nationalism in the late nineteenth century ${ }^{4}$. This administration held power until late 2016, winning four successive elections and subsequently governing in partnership with the largest party representing the Albanian minority, the Democratic Union of Integration (DUI) ${ }^{5}$. 
The type of government that was led by VMRO-DPMNE could be categorised as a "hybrid regime", now increasingly common in post-socialist countries ${ }^{6}$. According to_Katerina_Kolozova, a "hybrid regime” should be defined in patriarchal terms:

'...Typical of the state model at issue is the centrality of the role of a strong leader, such as Victor Órban in Hungary or Vladimir Putin in Russia. As a rule, it is an authoritarian figure enacting the essentially patriarchal role of paterfamilias whereby the nation is treated as a community of genetic kinship, a "family" (ethnos as genos) rather than a nation (or demos)... The general trait of the style of ruling is, I would argue, patriarchalism. The latter enables ethnocentrism, religious conservatism and strong state control. ${ }^{7}$

Nikola Gruevski sought to build for himself an image as a firm but fair patriarch; someone not afraid to make necessary reforms, but also someone who defended and defined the ethnic group for which he professed leadership; Macedonians. It should be noted that, by implication, Gruevski regarded the Macedonian nation as congruent with this largest ethnic group, rather than as representing a mix of differing ethnicities and religious beliefs.

Macedonian people who adhere to the Orthodox Christian faith may well constitute the largest ethno-religious group in the country, but to limit a definition of contemporary Macedonian statehood to this group, by implication, excludes Albanians, Macedonian Muslims, Roma people, and smaller ethnic minorities such as Aromanians, Bosniaks, Serbs and Turks from ever being regarded as full and equal citizens within the modern Macedonian state. This is a type of ethnic nationalism that, during Gruevski's tenure, was propagated through 'official' Macedonian culture, more so than in any other sphere of government influence.

It is in this context that we should approach the highly controversial Skopje 2014 programme, announced publically by VMRO-DPMNE planners in February 2010, and brought to an end, finally, after the new Social Democratic Party (SDSM)-led government took power in May 2017. This scheme was nothing less than the biggest 
'neo-classical' and 'Baroque' building scheme anywhere in the world, marking an official architectural policy of “antiquisation” from Gruevski’s government.

For proponents of the makeover, Skopje 2014 aimed at a truly Macedonian style of architecture; for opponents, it remains nothing more than aesthetically and architecturally illiterate kitsch, which has ruined the city ${ }^{8}$. At the time of writing this essay, what to do with the neoclassical and Baroque edifices, and sculptures, remains one of the thorniest problem that the new regime faces, not least because many of the commissions for these works are the subject of on-going legal proceedings that will take many years to conclude. For now, the city centre will be haunted by abandoned, half-finished building projects whilst the court cases and committees of experts continue their work.

The aim of this scheme was to alter profoundly the appearance of late Yugoslav Skopje. The city was eighty per cent destroyed by a disastrous earthquake on 26 July 1963, and was rebuilt in the following years with international help. The renowned Japanese architect Kenzo Tange devised a masterplan for the city centre, arranged according to his futuristic, modernist and visionary architectural principles ${ }^{9}$; a broader reconstruction plan for the urban area, was devised by the Polish architect Adolf Ciborowski, and the Greek architect Constantinos Doxiadis.

On the grounds of practicality and cost, only a small part of Tange's vision was completed, around the new railway station, south east of the city centre, whilst Soviet architects built new housing, in the Karpoš area to the west of the city centre; Poles contributed the new museum of contemporary art. Many other nationalities- Mexico, Bulgaria, Romania, Algeria, Finland and Sweden, from both sides of the Cold War divide, and from the non-aligned countries of the developing world, helped either physically, or in kind, in the re-construction effort.

Artists had been at the forefront of the re-building of Skopje after the calamity of July 1963, perhaps most notably in the work of the modernist painter and arts administrator Nikola Martinvoski (1903-73) and his tireless campaigning for the establishment of a Museum of Contemporary Art for Skopje. This institution, with the winning architectural design coming from Poland, was constructed in 1970 and 
sought to present an international collection of modern and contemporary art in order to better locate and inform the practice of local artists.

By contrast, the Skopje 2014 scheme was pre-determined politically and imposed without much regard to the contrasting opinions of the local art scene. Art in independent Macedonia has long been reduced to the status of what Gregory Sholette calls "bare art", in conditions where the arts economy does not function meaningfully owing to a collapse in audiences and available funding. In such circumstances, the artist merely fulfilling the role of a worker delivering a politically determined brief, without any agency to shape that brief through expertise or idea development. Its aim was not the re-shaping of artistic practice through exposure to international styles and connections, but rather the restriction of artistic possibility to the taste of the government of the day.

The aim of the Skopje 2014 scheme, then, is fundamentally a rejection of the rebuilding of Skopje in the 1960s and the 1970s on modernist and internationalist lines, and the international atmosphere that some remember in the city in the 1980s, in the last decade of Yugoslavia. Skopje 2014 was an attempt to dominate its public spaces ideologically, as well as re-casting its appearance physically. The architects of Skopje 2014 have sought to over-write or erase the previous appearance of Yugoslav Skopje, and to emphasise what they regard as the national identity of Macedonia.

Holding together this strange admixture of ethno-nationalism and neoclassicism was a strong streak of paranoid grievance and a betrayal myth. Confronted with evidence that the Macedonian security services has systematically bugged 20,000 citizens including top opposition politicians and journalists, the so- called "bombs" scandal that erupted in the early summer of 2015 , Gruevski sought to blame unnamed foreign intelligence services for fabricating all the evidence, a line that gained little traction beyond party loyalists. Gruevski sought also to blame George Soros and the NGO sector for the chronic political instability in Macedonia, and began a process of so-called "deSorosization" of Macedonian society right at the end of his period in office ${ }^{10}$. 
During the Gruevski years, especially after the rolling out of the Skopje 2014 project, artists of a critical mind_set who opposed the new policies of "antiquisation" responded in two broad ways; through collective action, and through humour.

Artists and activists responded in different ways to early crises in the run up to the public announcement of Skopje 2014. I have written elsewhere on Igor Toševski's ill-fated Territory on Plostad Makedonija, the capital's main square, in 2009. The work responded directly to rumours of the impending plans for a re-build of Skopje and, in particular, plans, to build a major Orthodox church on the square, that were abandoned subsequently.

In brief, this work utilised the forms of the early twentieth century Russian avantgarde to create a "free space" for citizens to perform in as they wished. Despite the work being a sanctioned part of an international art festival, municipal workers, on the orders of persons unknown, painted it out less than twenty-four hours after installation ${ }^{11}$. It was not the first time in Macedonia that a critical contemporary artist would find themselves trapped in a rip tide of fury; the artistic duo OPA (Obsessive Possessive Aggression) experienced a similar fate in a publically sited billboard piece in the summer of 2012, which was erased after a public outcry.

In the circumstances of the rolling out of Skopje 2014, and with pressure being exerted on those who dissented from it, the artistic collective KOOPERACIJA was founded in the spring of 2012, to provide a collective vehicle for creative and cultural discussion on the role of art in a hybrid democracy such as the Macedonia of that time. With a core membership of OPA, Toševski, Filip Jovanovski, Gjorgje Jovanovik and Nikola Uzunovski, this grouping organised exhibitions, discussions and events in empty commercial premises around the city, and in neighbouring countries. The artist and art historian Vladimir Janchevski, another member of KOOPERACIJA, recalled that

the important thing was that we were not all friends before that project started...the times of trouble brought us together and now these are important new friendships... what united is was the fact that what we all considered 
artistic, or democratic values were under attack, but not only that: we knew that new political reality and the cultural policies are little by little closing almost all doors for the future development of critical thought. ${ }^{12}$

KOOPERACIJA's approach was key in building dialogue between those who were involved in critical art, and those who were to become involved in activism. As such, it marked one of the earliest formations of this "alloy" between these overlapping, oppositional forces. This new alloy was tempered further in the attracting of a new audience for the products of contemporary art. Crucially, an institutional critique merged from these discussions, not only of the cultural policies of the Gruevski regime in regard to Skopje 2014, but also in exposing the impotence of the Macedonian cultural institutions - national galleries, academies, mainstream media - in holding the government to account for its decisions.

KOOPERACIJA was, in many ways, one of the first para-institutions in Macedonia; fulfilling the critical function one would expect from an institution, without the money or status. By the time of the discontinuation of the KOOPERACIJA project in 2015 , through a mixture of sheer exhaustion, and tactical differences in strategic response to contemporary political events, the grouping had established itself as one of the most significant and theoretically sophisticated contemporary art groupings not just in Macedonia, but in the ex-Yugoslav region ${ }^{13}$.

Another key response from critical artists during the Gruevski years, in response to the dizzying and claustrophobic over-writing of the familiar grid of the Skopje they knew, was to use understated, dark humour. Key early examples include Martin Bogdanovski's series Skopje You Will Shine of 2010-11, and the surreal cartoon humour of the Sviracinje collective, as well as the political choir Raspeani Skopjani. Aleksandar Spasoski's film, The Ship that Never Passed, completed in $2012 / 13$, is a useful text to consider this humorous strategy in more depth.

Spasoski's film engages with the sense of surreal dislocation felt by many citizens of Skopje, during the period of transformation from 2010 onwards, as the city and its former public spaces were transformed under Skopje 2014's planned programme of antiquization. In the film, centred on the iconic Ottoman-era stone bridge in the middle of the city ${ }^{14}$, we see large banks of speakers being arranged and set up under 
one of its arches. These speakers are then used to blast out the plaintive note of a cargo ship's horn- comically causing many passers by to turn around and look confusedly for the source of the noise.

Spasoski's film works on a number of other levels. It shows the ways in which Skopje 2014 not only stretched but constructed a parallel frame for what people may or may not have believed in times of constant change; if a number of huge, out of proportion neoclassical buildings and facades were erected in order to transform a city centre, then in that context it may not seem inconceivable that a cargo ship might navigate its way up the shallow waters of the river Vardar. In such ways, the artist attempts to engage the citizenry through the establishment of common ground makred by spatial dislocation and a comical subversion of reality.

The fine line between truth and lies, fact and fiction, and the elastic nature of facts in an era of "managed democracy" were all hinted at and played off against one another, in a gentle, humorous tension. The film uses the proposal of an alternative reality as a subtle critique of the "alternative reality" created by the government, in architectural terms, in the Skopje 2014 programme. Events subsequent to the making of this film - such as the bizarre appearance of mock wooden "galleons" by the banks of the Vardar, and the surreal intervention by unknown artists who planted fake shark fins in the river- prompting a response from Skopje's fire brigade - continued this dark and surreal response to contemporary events in Macedonia ${ }^{15}$.

\section{The Era of Protest and the Transition of Power}

Popular demonstrations against the government, in part based on the rather dubious nature of some of their latter electoral "victories", began early in 2015, peaked with a lengthy citizen occupation of the Ilinden boulevard, outside the national parliament, in the late spring and early summer of 2015. This was driven by the release of wire- tapped evidence described above, showing government ministers, including Gruevski himself, involved in corruption, election rigging, malfeasance and casual threats of violence against citizens ${ }^{16}$. 
Subsequently, the European Union, which had until that point fought shy of intervening too directly in the internal affairs of Macedonia, stepped in to broker the power-sharing "Pržino agreement", which was an international recognition that Gruevski's regime has lost any shred of democratic legitimacy. The agreement, signed between the governing VMRO, and Zoran_Zaev's Social Democratic Union of Macedonia (SDSM), aimed at stabilising day to day political relations in Macedonia, and paving the way for a possible election and transition of power.

Rather than bringing a speedy end to the crisis and ushering in a new era of cooperation, the Pržino agreement ushered in an agonising final eighteen months of sustained crisis. During this period, the colourful revolution (sarena revolucija), featuring huge citizen protests throughout the country, began on the $12^{\text {th }}$ April 2016. These renewed actions were prompted by the country's VMRO president, Gjorgje Ivanov, pardoning fifty six politicians, and other figures of interest, who had been recorded in the "bombs" scandal, as a means of, as he termed it, bringing the period of political crisis to an end ${ }^{17}$.

Ivanov's actions had the opposite effect, as protestors repeatedly_targeted new government buildings and monuments, symbolising the years of Gruevski. Buildings such as the president's residence, the Ministry of Justice and new monuments such as the triumphal arch just to the east of the city centre were covered in brightly coloured paint by protestors. These actions, as had been the case in Aleksandar Spasoski's The Ship that Never Sailed, saw a tense merger between surreal humour, ephemeral means and an urgent cutting edge in political terms. Loading rags and old clothes full of primary coloured paint, protestors fired these makeshift missiles at visible symbols of a corrupt regime, notable the Ministry of Culture, Ministry of Justice and the so-called "Triumphal Arch" to the south east of the main square. The strikingly visual nature of these protests were not lost on observers who had seen artists and activists working closely together to maximise meagre resources in what had seemed for a long time to be a punishingly unequal struggle between citizenry and government.

The demands of the colour revolution protestors included the resignation of the government and president, a transitional government of technical experts, and no elections until the political conditions in the country normalised. As a result, parliamentary elections organised for June were postponed for several months, and Ivanov was obliged to rescind his pardon in the heat of citizen anger. This vivid 
symbolic protest against government buildings and the new neoclassical monuments of the regime, gave this self-organised street movement an unstoppable momentum in demanding political change in the country.

It is this complicated, delicate and overlapping set of competing cultural and political discourses that framed the terrain for the production of contemporary art in Macedonia during the Gruevski years. In the transitional years of protest and change from 2015 onwards, Macedonia has been moulded between three political forces of varying strength; on the one side, the right wing VMRO-DPMNE; on the other side, the Social Democratic Union and various smaller left-wing and ethnically based political parties; the third, and by no means silent actor, in the resolution of the political crisis, was the international community, in particular the EU and the United States.

Following the results of the inconclusive Macedonian general election of December 2016, VMRO very narrowly emerged as the largest party, but one that has been unable to build a majority coalition amongst other parties. Subsequently, a new governing coalition emerged, in the early months of 2017, led by Zoran Zaev's SDSM and a bloc of Albanian parties, but this new coalition's assumption of power was hobbled by President Ivanov. Ivanov accused the SDSM of treason and seeking the dissolution of the unity of Macedonia, by caving into demands by Albanians for a programme variously described as federalism, secession, and indeed outright partition of the country.

If the international community seemed impotent in the face of such ethnically based charges, it was as a result of their indifference to the capture of the state apparatus by VMRO in the Gruevski decade. A final decisive attempt by VMRO to cling to power was the dramatic events in the Macedonian parliament of the $27^{\text {th }}$ April 2017. A right- wing extremist mob invaded the parliament as the SDSM-led coalition sought to assert their authority over proceedings, with the election of a new speaker, Talat Xhaferi. New Prime Minister Zaev was bloodied in a physical assault, and Defence Minister Radmila Sekerinska also severely assaulted to her injury. In this clumsily managed attempt to prolong the period of post-election transition, and thereby prolong the influence of VMRO, this shocking incident, beamed around the world on television, merely hastened the party's demise as a serious party of 
government ${ }^{18}$. The visible dissonance between the good-humoured, multi-coloured spatter of the colourful revolution protests, and the crude violence unleashed by this last desperate attempt to prolong the period of crisis, could not have been more stark.

\section{The New Normality: Critical Art and Protest after Gruevski}

This initial overview of events during the Gruevski years is essential to the understanding of the position of contemporary artists in North Macedonia. That government's characteristics of corruption, intimidation and casual violence marked both the oppositional response to it, and outlined the contours of possibility in responding to these conditions visually. It may fairly be said that the Macedonian citizenry, with artists prominent amongst them, received a hands-on political education during the years of protest from 2015-17. During this period, artists and political activists co-operated closely, and the lines between the two sectors of civil society became very blurred, not least in the ways in which the spectacle of protest became so aestheticized, in the Colourful Revolution events of April to July 2016. The characteristics of the colourful revolution protest- bright, ephemeral and humorous- may fairly be said to reflect many of the characteristics of contemporary art practice in the country, in conditions where the art economy barely exists, and where the cultural ecology is badly poisoned by long years of financial neglect and political manipulation.

In fact, since May 2017, artists from North Macedonia have had to adjust to a changed political landscape ${ }^{19}$. In the last two years ${ }_{2}$ artists and activists have sought to adjust to a "new normality" in Macedonia; to try to adapt activism and civic awareness for application in a new set of circumstances that is still emerging. It is difficult to draw precise lines between one set of circumstances and another, and the approaches that are emerging still, in what is now North Macedonia derive directly from those developed during the period of crisis.

Many figures prominent on the side of the protestors have subsequently entered government service following the changes of May 2017. The best known 
example is the author Robert Alagjozovski, who served in Zoran Zaev's first cabinet as Minister of Culture, until June 2018, before taking up a new role at the Prime Minister's office as national co-ordinator for the development of culture. In his year at the ministry Alagjozovski did much to change the managing personnel of Macedonia's atrophied Yugoslav-era cultural infrastructure, and to begin to draw up a plan for re-vitalising cultural activity beyond the main institutions in Skopje. On an institutional level, the appointment of Mira Gacina as director of the Museum of Contemporary Art has seen significant steps forward taken, in linking the museum with cognate institutions around Europe and raising its profile internationally through exhibition and discussion programmes. Artists, too, have taken up formal roles on committees administering cultural institutions and funding ${ }^{20}$.

For those artists who have not entered government, a further strategy for development can be found in the bourgeoning civil society sector, which has grown exponentially in terms of influence, funding, and reach in the last two years. Formerly regarded with great suspicion in the Gruevski years, and starved of government funding, this sector has always been able to act quickly in analysing cultural problems and suggesting solutions, in contrast to what can seem a dilatory and painfully inadequate response from government.

The joint work of the artist and cultural broker Filip Jovanovski and curator Ivana Vaseva is instructive in this regard. In the summer of 2016, following a series of discussions both in Skopje and in the eastern textile manufacturing city of Štip, they established the Artistic and Cultural Centre "TEKSTIL", in order to provide a space for local textile workers to organise themselves socially and politically, and to begin to think through some form of cultural programme responsive to their specific needs.

The plight of textile workers in Macedonian in the period of post-socialist transformation has been well documented. Of particular significance in the debate is Biljana Garvanlieva's 2010 documentary, The Seamstresses, which focuses on three examples of women working in very difficult, poorly remunerated conditions in the now privatised textile concerns of the $\mathrm{city}^{21}$; also the work of the academic Chiara Bonfiglioli on the collapse of the socialist-era textile sector in the countries of former Yugoslavia $^{22}$. The dreadful conditions facing textile workers in the modern textile 
industry in North Macedonia were highlighted when a female worker died at her post in 2015, of a heart attack brought on by heat and overwork; when this essay was in the process of being drafted, ten textile workers were hospitalised with measles ${ }_{-}^{23}$

TEKSTIL was launched officially in July 2016, in an abandoned restaurant, with an exhibition and a series of discussions on the textile sector. The aim of the project has been, in an activist manner, to try to harness the methodologies and social potentials of culture for the benefit of the workers who choose to engage with the sector. The project has developed exponentially since its foundation and has tried to give some shape to the discussions and working relationship between those engaged at the former socialist textile concerns, ASTIBO and Makedonska. The workforce is now largely privatised and divided between up to one hundred different companies, working across the two sites; cohesiveness and affinities of interest can be hard to discern in such circumstances.

TEKSTIL has been critical in beginning conversations and building networks of solidarity amongst a workforce that had experienced fear and intimidation, as well as very poor rates of pay and working conditions, in the late Gruevski years; the situation for local workers counted for little as the government sought to make former Macedonia attractive to foreign business. The potential of this project to create a rupture in local politics was shown when thugs rumoured to be associated with VMRO-DPMNE attacked the centre ${ }^{24}$.

Since the project has begun, the workers have driven the programme, rather than artists and curators; a newspaper has been produced, active work has gone into rekindling annual festivals (Tekstilijada) that used to be showpiece events in socialist times; TEKSTIL has also seen the founding of an NGO and advocacy group, LOUD, working on labour rights and associated socio-political issues. As Ivana Vaseva explained:

Jovanovski, starting from his conscious position of an artist, and thus, a cultural worker, together with his collaborators from the art world, on a level of solidarity also based on respect, together with the textile workers from this local context and their supporters, opened this centre for the needs of the textile, leather, and shoe workers from the city, as well as the country. In this 
case, a socially engaged work created relations and relationships that were previously difficult to establish in the local context, and gave visibility to a marginalized category of textile workers in eastern Macedonia. Through art and culture or within the frames of the contemporary artistic production, the problems of this group of workers became visible, thoughts were prompted on how to unite their problems and seek the right approach in changing the conditions and the ways in which they work. ${ }^{25}$

TEKSTIL is a key example, in its various activities, of the ways in which art and activism have fused in an interesting way; to come together and enhance one another's potential to try and find a structure to meet the needs of the local working classes, and to help in their organisation and development in the years since its foundation, as well as to build networking capacity. It is not a project oriented around exhibitions and residencies, but a cultural framework established to enable local people to begin to shape the cultural offer of the city.

During the period of the Gruevski government, a noted undercurrent in critical contemporary art, was artists and cultural workers who continued to use the methodologies and tools of art, without actually producing art objects. This is an attitude summed up by the art historian and activist Bojan Ivanov, who opined famously that: "I am no longer interested in art, but I am still very interested in artists. ${ }^{26}$ Whilst, in part, this statement reflects a general collapse in the object-based cultural ecology of the former Yugoslavia, and early Macedonia, it also reflects the adaptation of some Macedonian artists to conditions described by the American art activist and writer Gregory Sholette as "bare art":

Culture's internal aesthetic character is now manifest as so many flagrant, unconcealed and utterly ordinary attributes, so many data points, so that the desire by 1960 s artists to transform their elite social position into that of a 'cultural worker' has finally been fulfilled. Today artists are simply another worker, no more no less. We might best describe this... as simply bare art."27 
In many ways, contemporary art in North Macedonia that employs activist strategies worries at the scars of late modernism. The TEKSTIL project is one such trying to give art a meaning and a community relevance beyond the production of objects.

Whilst a whole system of galleries and exhibitions still exist in North Macedonia, the middle class audiences that populated them in the late 1980s have vanished through the linked processes of privatisation, the loss of a sense of commons, immiseration and the structures of contemporary "flexible" labour. Moreover, the institutions of contemporary art subsist on a small fraction of the money that was available during Yugoslav times; a vanishingly small number of Macedonian artists, those who are able to maintain a nomadic international practice from a base in the country, are able to live full time from art with many others working either in jobs in the academy, or in design agencies, to buy time to keep their art practice going.

A project that is critical to consider in this context is OPA Fondacija's online archive of Macedonian art. During 2016, OPA, the artistic duo Denis Saraginovski and Slobodanka Stevčeska, underwent a process of re-evaluating their activities and decided to de-emphasise the production of art works in favour of tasks which support the development of and capacity for art infrastructure in the country. In their own words:

It [OPA Fondacija] focuses on developing practical utilitarian solutions and constructive art practices as an alternative to critical ones. It arose from the necessity for a direct contribution to the community and with a strong belief that solidarity and education are crucial for today's world. ${ }^{28}$

They divided their activities; OPA Professional was the side of their work that still engaged in the making and discussion of art works, whilst OPA Fondacija was the side of their work that focused on developing and building infrastructure.

Key in this task is the building and development of the on-line Arhiva ZAUM, a project that has been in development for three years now. This is an ever-growing 
archive of resources that deals principally with writing and documentation relating to modern and contemporary art in Macedonia.

In other countries the task of building such a resource falls to institutions, yet since independence in 1991 Macedonian institutions have singularly failed to address the problem of collective memories of visual culture in the country. These problems were brought into painful focus with the steady destruction of some of the rich international modernist heritage of Skopje; for example, the destruction of the modernist painter Borko Lazeski 's (1917-93) murals on the National Liberation War, at a mysterious and unexplained fire in Skopje's central post office in January 2016, or the ruinous fire at Skopje's Institute for Town Planning and Architecture in April 2017, which caused the irreparable loss of much history relating to the rebuild of the city in the $1960 \mathrm{~s}^{29}$.

OPA Fondacija's Arhiva ZAUM, therefore, addresses three separate crises in contemporary visual culture in North Macedonia, by means of activist tactics. Firstly, it exposes the complete failure of cultural institutions in the country to safeguard and develop the national archival holdings for contemporary scholars and for future generations. Part of the political problem in North Macedonia is the constant ideological over-writing and re-telling of history, that the erosion and loss of archival holdings facilitates. Secondly, the archive continues a discussion begun under the aegis of KOOPERACIJA earlier in this decade, on the public commons; who owns the nation's collective cultural memory, according to what programme, and with what expected consequences. The project continues to highlight the indifference in which the rich modernist legacy of Skopje and the former Yugoslav period is held by many citizens, who are aware that these are artefacts from past times and struggle to see their relevance in a much changed present. Finally, the project symbolically occupies space left behind by the retreat of the state in cultural activity during the Gruevski years, and acknowledges that retreat by occupying the vacated space through taking on the function one would normally expect from a government organisation.

\section{Conclusion}


Brought into existence after the collapse of Yugoslavia, FYROM was a state of permanent in-between-ness, a diplomatic sleight of hand that lasted much longer than anyone expected. In its first twenty-five years, this fledgling state was trapped between an atrophying Yugoslav past and a confusing, hostile, corrupted present. This marked a dizzying contraction of opportunity, the fading of a world where a Yugoslav passport granted trouble free entry to most states on either side of the ideological divide; between the infrastructure of socialism and the emergence of a corrupted gangster capitalism; between attempts to build a sense of self, and attempts to have that sense of self denied; an uncertain place between periphery and semi-periphery, between the global South, and the razor-wire fences surrounding the EU club.

It is this liminal state, the current crisis of a new normality, that artists and activists are now seeking to mould in different ways, in a new country. We have seen in this essay how the cartography of the visual in Macedonia was re-drafted, fundamentally, by the government of Nikola Gruevski, in the years 2010-17. We have considered responses to the Skopje 2014 project, through an engaged collectivism, and through humour. In the practices that are continuing to emerge and establish a new hegemony in the years since May 2017, we are beginning to see how those strategies are mutating in the emergence of a new polity. In some ways, the contemporary art world in North Macedonia has adopted the form of art worlds in the former Warsaw Pact countries of the early 1990s; artists are having to adapt to a changed landscape where the certainties of opposition and clear enmities exist no more, and new topics have to be found and developed. As we have seen, these topics have included using the instruments and methodologies of contemporary art to meet and challenge the needs of the communities in which they are located. This is a new alloy of allies, whose process of formation will be fascinating to observe in the challenging times that lie ahead for North Macedonia, as the current political class seeks to face down opposition and integrate the country fully with NATO and the European Union.

Following the French veto of the opening of talks for EU membership both for North Macedonia and Albania on 18 October 2019 ${ }^{30}$, and with Prime Minister Zaev calling for fresh elections in 2020 , in the wake of this decision, where this severe blow to the Euro-Atlanticist integration path will leave the country's artists and art institutions, remains anybody's guess. 


\section{Acknowledgements}

I am grateful to my friends and colleagues Bojan Ivanov, Filip Jovanovski, Denis Saraginovski, Slobodanka Stevčeska, and Ivana Vaseva for ongoing conversations on the subject of art, activism and politics in contemporary North Macedonia.

\section{References}

\footnotetext{
${ }^{1}$ Although Macedonia declared independence in September 1991, it was not officially recognized by the United Nations until 13 April 1993, in the face of Greek objections to the name "Republic of Macedonia". From the Greek perspective, this name implies a territorial claim on the Greek region also called Macedonia. Following the assumption of power by a social democratic coalition in the country in May 2017, progress was made towards the re-naming of the country as "North Macedonia", enshrined in the Prespa agreement signed by the Macedonian and Greek governments on 17 June 2018, and subsequently ratified in narrow, tense votes in favour, in both parliaments in Skopje and Athens.

2 The Macedonian insurgency began in late January 2001 and was terminated by the signing of the Ohrid agreement, between the political representatives of the state government and National Liberation Army insurgents, in August 2001. The insurgency claimed 1,000 casualties in total, of whom between 150-250 were killed.

${ }^{3}$ In the original Macedonian, the party name reads Vnatreshna makedonska revolucionerna organizacija - Demokratska partija za makedonsko nacionalno edinstvo

${ }^{4}$ VMRO- which stands for Internal Macedonian Revolutionary Organisationtraces its origins to 1893 and the foundation of TMORO (Secret Macedonian Revolutionary Orgnaisation). This became VMORO (Internal Macedonian Revolutionary Organisation) sometime around the turn of the nineteenth and twentieth centuries. The organization re-emerged after the Great War as a part of a greater Bulgarian political project, and lasted until 1934, when it was forced underground and outlawed, in the Kingdom of Yugoslavia. The present-day VMRO-DPMNE- (Internal Macedonian Revolutionary Organisation- Party for Democratic Renewal), is a new party, founded on 17 June 1990, which claims ideological descent from the original grouping. Hristjan Mickoski took over the leadership of VMRO-DPMNE from Gruevski in December 2017, and continues to lead the party in opposition. I am grateful to Bojan Ivanov for discussions on the
} 
history and development of VMRO. See also Boskovska, N (2017), Yugoslavia and Macedonia before Tito: Between Repression and Integration, London: I.B. Tauris 5 The DUI (Democratic Union for Integration) was founded in 2001, under the leadership of Ali Ahmeti. The DUI , as a political organization, grew out of the ethnic Albanian National Liberation Army (NLA), which briefly fought with government forces in the 2001 Macedonian insurgency. The military conflict was brought to an end by the signing of the Ohrid agreement, which saw the NLA disarmed, and the DUI, amongst other ethnic Albanian parties, founded.

${ }^{6}$ Kolozova 2015, p. 7

${ }^{7}$ Kolozova, 2015, pp. 8-9

${ }^{8}$ See, for example, Dejan Bugjevac, “Critics Lash 'Dated' Aesthetics of Skopje 2014", Balkan Insight, 24 June 2010

(https://balkaninsight.com/2010/06/24/critics-lash-dated-aesthetics-ofskopje-2-aa4/); Jasna Koteska, "Troubles with History", ArtMargins Online, 29 December 2011 (https://artmargins.com/troubles-with-history-skopje-2014/), Guy de Launey, "The Makeover that's Divided a Nation”, BBC News Magazine, 30 August 2014 (https://www.bbc.co.uk/news/magazine-28951171)

${ }^{9}$ See Lin, Zhongjie (2010), Kenzo Tange and the Metabolist Movement: Urban Utopias of Modern Japan, Oxford: Taylor \& Francis. See also "Kenzo Tange's Reconstruction Plan for Skopje" at http://tststsss.tumblr.com/post/8342830969/kenzo-tange-reconstructionplan-for-skopje

${ }^{10}$ See Gordana Knezević, “Macedonian Witch-hunt targets George Soros”, Radio Free Europe / Radio Liberty,, 29 January 2017.

(https://www.rferl.org/a/george-soros-macedonia-witch-hunt/28243738.html) 11 See Blackwood 2016, pp. 58-60, also interview with Igor Toševski, pp. 182-99; see also my "Censoring Contemporary Art in Macedonia" in Kennedy \& Coulter, 2018, pp. 145-49.

12 Blackwood 2016, interview with Vladimir Janchevski, p. 244.

${ }^{13}$ For an introduction to the key questions KOOPERACIJA sought to address, see Kooperacija (2014) "Art and Politics? Kooperacija”, Reader: Balkans, Open Systems journal, accessible online at: http://www.openspace-

zkp.org/2013/en/journal.php?j=5\&t=32\#bio

14 The Stone Bridge was erected between 1451 and 1469 in the era of Sultan Mehmed II. It features on the city's present day coat of arms (designed by Vasilije Popović-Cico in the 1940s) and on many corporate logos from hotels to local football clubs.

${ }^{15}$ Yanita Georgieva, "Fighting Art with Art”, euronews.eu, 19 April 2016.

Accessible at: http://www.euroviews.eu/2016/2016/04/19/fighting-art-withart/ Last accessed 21 May 2019

${ }^{16}$ For the full transcripts of the "bombs" tapes and evidence of Gruevski's involvement in these crimes, readers can visit al-Jazeera's interactive coverage of the scandal at https://interactive.aljazeera.com/ajb/2015/makedonijabombe/eng/index.html. We should also state that Gruevski was sentenced to two years in prison on 23 May 2018, having been convicted of charges of 
"receiving rewards for illegal influence", relating to the purchase of an armoured Mercedes car. (https://kosovotwopointzero.com/en/nikola-gruevski-sentencedto-two-years-in-prison/) Gruevski was facing further criminal actions beyond this, but was spirited away to Hungary before he was due to report to serve his prison sentence. Hungarian Prime Minister Viktor Orban granted Gruevski, a long time ally, political asylum, on 20 November 2018

(https://uk.reuters.com/article/uk-macedonia-hungary-gruevski/exmacedonia-pm-gruevski-says-he-has-been-granted-asylum-in-hungaryidUKKCN1NP1JD)

${ }^{17}$ See BBC World, "Macedonian Protests; Anti-Gruevski Rally in Skopje”, 17 May 2015, accessible at: http://www.bbc.co.uk/news/world-europe-32771233 ${ }^{18}$ Sixteen individuals received long prison sentences for their involvement in the attack on parliament on the $27^{\text {th }}$ April 2017. Former interior minister Mitko Cavkov was sentenced to eighteen years' imprisonment for terrorist endangerment of the constitutional order of the republic.

${ }^{19}$ Elsewhere, I have written about the differing positions that artists adopted during the response to the Skopje 2014 scheme; positions of active involvement and support, "neutral" silence, or opposition in various ways. This part of our discussion is concerned primarily with the latter two categories. See Blackwood (2016), pp. 30-55 ${ }^{20}$ Examples include the painter, performer and cartoonist Gjorgje Jovanovik (b.1980).

${ }^{21}$ Biljana Garvalieva, The Seamstresses, Macedonia/ Germany, 2010, produced by Dream Factory Macedonia.

${ }^{22}$ See Bonfiglioli, 2019. I am grateful to Ivana Vaseva for drawing my attention to Bonfiglioli's work.

${ }^{23}$ http://www.english.republikanka.mk "Ten Textile Workers Hospitalised in difficult condition after a measles outbreak in Stip", 26 May 2019, accessed 29 May 2019

${ }^{24}$ Anastasija Petrevska, "Attack on NGO fighting for rights if Textile Workers highlights Dangers to Civil Society", Global Voices, 2 December 2016. Accessed 14 April 2019.

${ }^{25}$ Interview with Ivana Vaseva, 14 October 2018

${ }^{26}$ See Blackwood 2016, interview with Bojan Ivanov, p. 300.

27 Sholette, 2017, p. 13

${ }^{28}$ See http://o-p-a.org/

${ }^{29}$ See e-flux, "Skopje's History on Fire", 10 May 2017. https://www.eflux.com/announcements/132731/skopje-s-history-on-fire/ Accessed 14 May 2019

30 The progress made by North Macedonia towards opening talks for EU membership was brought to a shuddering halt by French president Emmanuel Macron at a summit of EU leaders on 18 October 2019. France vetoed the opening of talks with both North Macedonia and neighbouring Albania, in a move denounced variously as "deplorable" and "a historic mistake". French objections centred on the need to reform the processes associated with acquiring EU membership. https://www.independent.co.uk/news/world/europe/euenlargement-emanuel-macron-albania-north-macedonia-junckera9161536.html 